\title{
Education of Inorganic Waste Management Through Training of Creations
}

\author{
Nurlita Juliana ${ }^{1 *}$ Jumriani $^{1}$ Syaharuddin ${ }^{1}$ Karenina Panca Kiranti ${ }^{1}$ \\ ${ }^{1}$ Faculty of Teacher and Training, Lambung Mangkurat University, Banjarmasin, Indonesia \\ ${ }^{*}$ Corresponding author. Email: nurlitajuliana26@gmail.com
}

\begin{abstract}
Training in managing inorganic waste into various recycled creations is a means to increase public knowledge and empower inorganic waste management. This article aims to describe inorganic waste's power into different recycled designs in Kampung Hijau, Kelurahan Sungai Bilu. The report was compiled from the results of community service in Kampung Hijau, Kelurahan Sungai Bilu. The service results are then described and reviewed using literature studies in books and scientific journals. The method used at the service was the delivery of material, discussion, and practice of processing inorganic waste into various creationsThehe activity results described training in the management of inorganic waste into different recycled products to increase public knowledge. The government and all social levels should pay special attention to the use and management of garbage in various creations by applying the 3D principle (starting from small things, starting from now, starting with oneself) in everyday life.
\end{abstract}

Keywords: Education, recycling, inorganic waste.

\section{INTRODUCTION}

A clean and free environment from rubbish is one thing that is expected by every community. Creating a clean and open environment from piles of garbage will create a comfortable and pleasant atmosphere [1,2]. Even so, environmental cleanliness is still an issue in people's lives. Garbage is an ecological problem that, until now, has not been appropriately handled. Managing waste is characterized by an imbalance between waste production and management, resulting in accumulation. Garbage that is not collected will result in bad environmental quality. The impact is in contaminating soil, water, and air and reducing the environment's esthetic value. One of the factors causing waste accumulation is the difficulty in collecting, transporting, disposing of, utilizing, and destroying waste, both wastes originating from households, markets, industry, and office waste [3].

The problem of waste should be a severe concern for the community, considering the various kinds of environmental disturbances caused by accumulated garbage. The disruption caused by inorganic waste such as plastic, rubber, and cans cannot rot and decompose from the earth quickly, so that recycling techniques are needed to reduce the volume of this type of waste. It takes 1000 years for plastic waste decomposed by the soil in a threatening or perfect manner [4].

According to INSWA (Indonesia Solid Waste Association), the use of plastic in Indonesia itself has now reached 3 million tons per year. Unfortunately, plastic waste is often seen as a waste of human activity that is useless and tends to be thrown away. 3M's efforts (reduce, reuse, and recycle) have not been realized by the community and consider that the responsibility for environmental hygiene is in the government's hands. Most of the plastic waste generated from community activities is a type of plastic that can be recycled [5].

Plastic waste, especially those in the form of bottles, has a great potential to be recycled into various kinds of products that can increase the economic value of plastic bottle waste itself. Seeing the opportunity to improve the monetary value of the use of plastic bottle waste, supported by the volume of plastic bottle waste produced by the community, training is needed for residents in an area to manage waste into various creations, so that it is beneficial from the social and economic perspective of the community $[6,7]$.

The existence of teenagers in an area can be used to manage plastic waste into various creations. Adolescents potentially have attitudes that show very high awareness and interest in science. Therefore, a breakthrough to optimize the regeneration of plastic waste recycling by youth is an opportunity to encourage the development of plastic waste management.

Based on the description above, this article aims to describe the results of youth empowerment service in Kampung Hijau, Sungai Bilu Village through training in recycling inorganic waste into various creationsThisis service results are expected to be a source of education for the local community on how to recycle inorganic waste and develop it into a source of income for the community.

\section{METHOD}

This article is compiled from the results of community service in Kampung Hijau, Kelurahan Sungai Bilu. The main thing behind this dedication is related to the importance of inorganic waste management. It provides 
benefits for the quality of the environment and the life of the community.

Kampung Hijau Kelurahan Sungai Bilu was chosen as a service place because the village is part of a local government program known as the climate village. The identity of the climate village is closely related to the quality of the environment. Therefore, to be involved in government programs, the Social Studies Education Study program provides inorganic waste management services in green villages as climate villages in Banjarmasin City.

The implementation mechanism is carried out in three forms of activities: first, a discussion about the types of waste and their management. Second, training in inorganic waste management. Third, the practice of inorganic waste management becomes various creations. The activity was carried out in September 2020. Specifically, here are the details of the activity:

Table 1 Service Implementation Schedule

\begin{tabular}{|c|c|c|c|}
\hline No & Day / Date & Time & Location \\
\hline 1 & Saturday, 12 September 2020 & $09: 00$ to 12:00 Wita & $\begin{array}{c}\text { Village Youth Group } \\
\text { Secretariat }\end{array}$ \\
\hline 2 & Saturday, 19 September 2020 & $14: 00$ to 16:30 Wita & $\begin{array}{c}\text { Village Green Youth Group } \\
\text { Secretariat }\end{array}$ \\
\hline 3 & Saturday, 26 September 2020 & $16: 00-17.30$ Wita & $\begin{array}{c}\text { Village Green Youth Group } \\
\text { Secretariat }\end{array}$ \\
\hline
\end{tabular}

Source: Researcher Data, 2020

To strengthen community service results, the results of activities were analyzed using literature studies obtained from various sources such as books, scientific journals, reports from research bodies that are accurate and relevant to the concept of inorganic waste management and environmental care. The results of activities and literature studies are compiled in narrative form by first going through a data reduction process. Data reduction makes it easier for the author to select data from the literature validly while presenting the narrative form data. The results and discussion and conclusions in this article are the results of an analysis of various relevant scientific sources to discuss waste management training activities into various recycled creations for youth groups in Kampung Hijau, Kelurahan Sungai Bilu, Banjarmasin City.

\section{RESULTS AND DISCUSSION}

This community service activity was carried out to raise ideas and increase public awareness of the importance of managing inorganic waste into various creations by youth in Kampung Hijau, Kelurahan Sungai Bilu. Waste production is increasing day by day. To minimize the presence of debris, a recycling process is needed, especially inorganic waste. Garbage is one of the causes of environmental problems that require serious attention to deal with it.

The utilization of plastic waste by recycling is generally carried out by industry. In general, there are four requirements so that plastic waste can be processed by an enterprise, including waste that must be in a specific form as needed and not contaminated, and strive not to be oxidized [5]. To overcome this problem, before use, plastic waste is processed through simple steps, namely separation, cutting, washing, and removal of substances such as iron and so on. Waste recycling carried out by the industry is through separating plastic waste, cutting plastic waste, washing plastic waste that has been cut beforehand, and removing harmful substances from plastics after plastic waste is cut. Besides recycling carried out by industry or factories, plastic waste recycling can also be done by reusing items from plastic waste. The use of recycled plastics in the remaking of plastic goods has proliferated $[8,2]$.

Community service activities in Sungai Bilu Village are carried out in three stages; namely, the first activity is carried out by socializing waste management into various creations through the material presented. This socialization can run smoothly, which is indicated by the youth's enthusiasm in discussing waste management into different recycling creations Adolescents'nt's understanding of the socialization of inorganic waste management into various recycling and economic production youth in Kampung Hijau, Sungai Bilu Village is quite good. This service activity opens the way teenagers think or ideas about waste management.

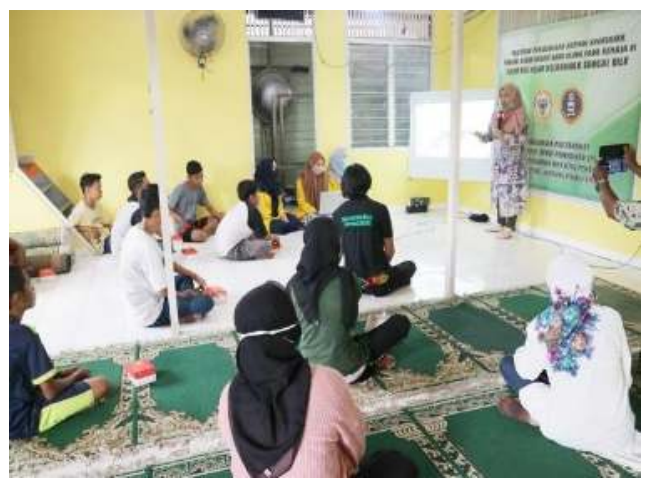

Figure 1 Community Service Activities in Kampung Hijau, Kelurahan Sungai Bilu 
Second, community service activities are carried out using the demonstration method. The community service team provides examples and practices on managing inorganic waste into various creations through video viewing. Furthermore, the youth practiced how to process inorganic waste into different recycled designs using the equipment provided. Third, applying the discussion method is carried out so that the community, including adolescents, better understand the explanations that have been conveyed and can be given opportunities for youth to be more active and provide opportunities to ask questions and exchange ideas and experiences. After the community service implementation is complete, the community service team conducts an evaluation to determine the level of understanding of the teenagers through the practice of making various creations from inorganic waste using available equipment.

Based on the results of these activities, several efforts can be made to reduce the volume of waste; the four (3R) principles that can be used in dealing with waste problems are as follows: a. Reduce (lower), namely trying to minimize the goods or materials that we use. b. Reuse (reuse), i.e., choose items that can be used again, avoid using disposable items(disposable).c. Recycling, namely entities that are no longer useful, can be recycled to have added value $[9,10]$.

In this service, the focus is more on discussing Recycle or recycling. Recycling is the process of turning used materials into new materials to prevent waste that can be useful, reduce new clothing materials, reduce energy use, reduce pollution, land degradation, and greenhouse gas emissions compared to the manufacturing process. Recycling is one of the concrete waste management strategies, consisting of sorting, collecting, processing, distributing, and manufacturing used products or materials and a significant component in modern waste management [11].

Solid waste can be recycled by separating, collecting, processing, distributing, and making it into reusable items. Solid waste is also the main ingredient in the recycling process. Garbage can pollute the environment and endanger health. Garbage also causes flooding. However, through recycling, waste can be processed again into useful items. Waste recycling is reprocessing useless things into valuable items [12].

Waste recycling in the community can be done in several ways, including manual recycling of waste and recycling carried out by factories. Waste that is recycled manually usually comes from objects, such as plastic, paper, cardboard, iron, copper, bone, glass, etc. Recycling carried out by the factory also requires raw materials from plastic, glass, iron, paper, copper, band one, depending on the factory's production. Garbage has various types; the processing of waste varies with trash $[13,14]$. Waste processing can be done manually by being processed directly by a human and processed by factories. Waste that is processed manually is usually in the form of creations and products processed with creative ideas. Waste that is processed by factories usually becomes the same product as items that have been recycled before [14].
Garbage consists of various types and can be reused so that waste items that were previously only trash can turn into useful things. Recycling of waste already has a high economic value in developed countries. There are many factories for recycling waste; they make the waste as raw material for specific products; this increases the object's economic value. Good waste management provides two essential benefits: reducing environmental pollution and utilizing waste to increase the item's monetary value.

\section{CONCLUSION}

Inorganic waste is garbage that does not come from living things. Inorganic waste takes a long time or cannot even be degraded naturally. One of the uses of inorganic waste is by way of the recycling process (recycle). Recycling is an effort to process goods or objects that are no longer used to be reused. Some inorganic wastes can be utilized through the recycling process, for example, plastics, glass, and paper.

Waste handling as a product that is no longer useful and tends to be thrown away should be changed. Waste management requires effort and awareness of the right and appropriate waste utilization and power to be developed in every community environment. The quality of health, environmental quality can be improved, and waste can become a resource that can be used to improve community welfare.

\section{REFERENCES}

[1] A. Apriyani, M. M. Putri, and S. Y. Wibowo, "Pemanfaatan Sampah Plastik Menjadi Ecobrick," Masy. Berdaya dan Inov., vol. 1, no. 1, pp. 48-50, 2020.

[2] A. Minelgaite and G. Liobikienè, "Waste problem in European Union and its influence on waste management behaviours," Sci. Total Environ., vol. 667, pp. 86-93, 2019, doi: 10.1016/j.scitotenv.2019.02.313.

[3] J. Mesman, I. L. Bongers, and H. M. Koot, "Preschool developmental pathways to preadolescent internalizing and externalizing problems," J. Child Psychol. Psychiatry Allied Discip., vol. 42, no. 5, pp. 679-689, 2001, doi: 10.1017/S0021963001007351.

[4] D. Gusmarti et al., "TIN : Terapan Informatika Nusantara Pemanfaatan Limbah Sampah Rumah Tangga Untuk Mengurangi Pencemaran Lingkungan di Permukiman TIN: Terapan Informatika Nusantara," TIN Terap. Inform. Nusant., vol. 1, no. 4, pp. 154-156, 2020.

[5] T. Chowdhury et al., "Latest advancements on livestock waste management and biogas production: Bangladesh's perspective," J. Clean. Prod., vol. 272, p. 122818, 2020, doi: 10.1016/j.jclepro.2020.122818. 
[6] K. S. Ng, A. Yang, and N. Yakovleva, "Sustainable waste management through synergistic utilisation of commercial and domestic organic waste for efficient resource recovery and valorisation in the UK," J. Clean. Prod., vol. 227, pp. 248-262, 2019, doi: 10.1016/j.jclepro.2019.04.136.

[7] A. Maulida, "THE ANALYSIS OF ECONOMIC ACTIVITIES OF WASTE RECYCLING SCAVENGERS IN TERJUN URBAN VILLAGE MEDAN MARELAN SUBDISTRICT," $Q E J$, vol. 08, no. 01, pp. 1-18, 2019.

[8] D. Burneo, J. M. Cansino, and R. Yñiguez, "Environmental and socioeconomic impacts of urban waste recycling as part of circular economy. The case of cuenca (Ecuador)," Sustain., vol. 12, no. 8, 2020, doi: $10.3390 /$ SU12083406.

[9] N. R. Ambati, "Social innovation practices in sustainable waste management: Case study of successful social enterprises in Ahmedabad," Int.
J. Sci. Technol. Res., vol. 8, no. 12, pp. 19781985, 2019.

[10] L. A. B. Paes, B. S. Bezerra, R. M. Deus, D. Jugend, and R. A. G. Battistelle, "Organic solid waste management in a circular economy perspective - A systematic review and SWOT analysis," J. Clean. Prod., vol. 239, 2019, doi: 10.1016/j.jclepro.2019.118086.

[11] L. Sulistyorini, "Pengelolaan Sampah dengan Cara Menjadikannya Kompos," J. Kesehat. Lingkung. Unair, vol. 2, no. 1, p. 3951, 2005.

[12] Triana and D. Sembiring, "Manajemen pengolahan sampah: Pengolahan sampah, murah, efektif, efisien dan cepat," 2019.

[13] M. Yuniwati, F. Iskarima, and A. Padulemba, "Optimalisasi Kondisi Proses Pembuatan Kompos Dari Sampah Organik Dengan Cara Fermentasi Menggunakan EM4," J. Teknol., vol. 5, no. 2, pp. 172-181, 2012.

[14] I. Yuliati, Aksesori dari kertas: Memanfaatkan kertas menjadi berbagai macam aksesori cantik. Surabaya: Tiara Aksa, 2011. 